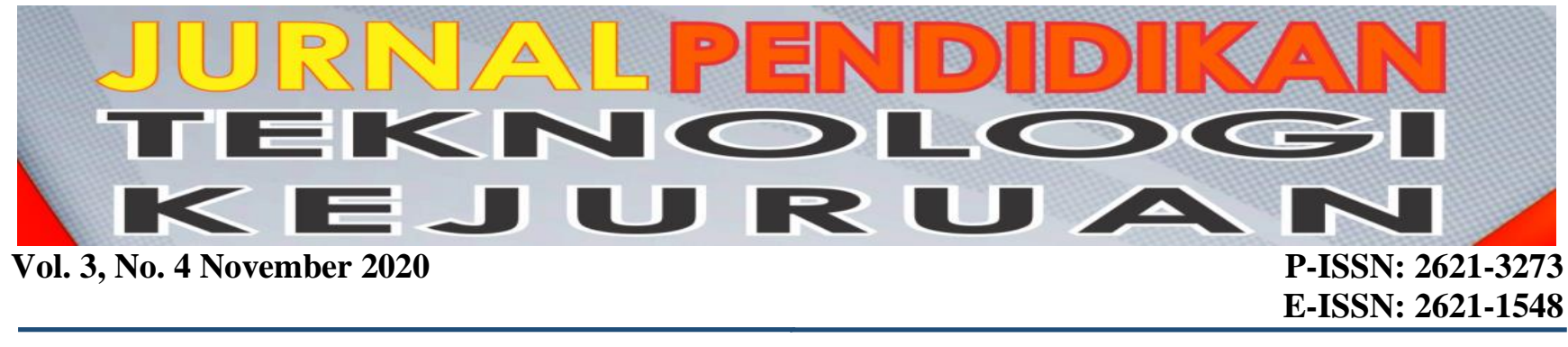

\title{
Development Of Entrepreneurship In Students Technology Based University Of Lancang Kuning Pekanbaru
}

\author{
Abrar Tanjung', Ambiyar ${ }^{3}$, Unung Verawardina ${ }^{3}$, Junil Adri ${ }^{4}$, Vivi Efrianova ${ }^{5}$, \\ Ferdiansyah $^{6}$, Fani Keprila Prima ${ }^{7}$ \\ ${ }^{1}$ Teknik Elektro Fakultas Teknik Universitas Lancang Kuning \\ ${ }^{2,4}$ Pendidikan Teknik Mesin Universitas Negeri Padang \\ ${ }^{3}$ Pendidikan Teknologi Kejuruan, Fakultas Teknik, Universitas Negeri Padang \\ ${ }^{5}$ Tata Rias dan Kecantikan, Fakultas Pariwisata dan Perhotelan, Universitas Negeri Padang \\ ${ }^{6}$ Teknik Informatika dan Komputer, Fakultas Teknik, Universitas Negeri Padang \\ ${ }^{7}$ Pendidikan Teknik Bangunan Fakultas Teknik Universitas Negeri Padang \\ Correspponding author e-mail : abrar@unilak.ac.id
}

\begin{abstract}
Technopreneur, one part of the development of entrepreneurship (entrepreneur), provides a picture of entrepreneurship using technology-based innovation. The technopreneur concept is based on a technology base that is used as an entrepreneurial tool, for example the emergence of an online application business and a security system business. The purpose of this research is to conduct a descriptive study of entrepreneurship in students using technology (Technopreneurship) from all perspectives, including motivation, ownership, managerial, employment, and so on. technology as a basis for entrepreneurship. The results of the discussion found that the use of technology (Technopreneurship) in entrepreneurship can help and develop businesses in the form of making products and in marketing the products, so as to increase business and student income.
\end{abstract}

Keywords : Technopreneur, entrepreneurship, students

\section{INTRODUCTION}

The demands of various problems in society eventually gave birth to a concept called entrepreneurship. The concept of entrepreneurship is the art of changing problems or opportunities that exist in society so as to generate new creative ideas that can create solutions that are beneficial to others. The problems that exist in the community are observed and analyzed, then take solutions to meet the needs of the community. In the last few years, this concept has been growing, even now there are many young entrepreneurs who come with bright ideas. Many ideas, products, or services are usually modified and combined to produce new ideas, products and services. Creativity gives birth to a variety of products that are not ordinary (Akmaliah et all, 2009 ; Anata et all, 2013). Technopreneur is a combination of opportunities that are seen and the use of existing technology. Trading via the internet or creating applications in cyberspace has become a trend in today's society. If entrepreneurs are usually bound by work time and business costs, now technopreneurs don't need to think about these two things, because technopreneurs don't need physical space and also don't have rental fees or other costs. Technopreneurs get out of the ruts of society in general. If in general, college graduates are competing to find work, then technopreneurs are the originators of employment with a new concept. For these reasons, the MMSI study program provides specialization in technopreneurs. It is hoped that these postgraduate graduates can open their own business opportunities and provide jobs for others (Asri Laksmi Riani. 2005)

Technoprenuership is a development of the entrepreneurial concept. Entrepreneurship is one of the answers to addressing the disparity between the growth of the productive age population and the availability of jobs. The world of education is obliged to be able to produce generations that have independence, including economic independence. 
Schools, campuses as well as other informal educational media do not only function to share knowledge with theories and skills with practices. But if it is associated with the low understanding and interest of the world of entrepreneurship, the world of education can also function as a medium of information to increase the understanding and interest of students in the world of entrepreneurship. To increase interest in entrepreneurship / entrepreneurship, one of which is by increasing public understanding and interest in the field of entrepreneurship. According to Tuker and Senen 2009 that entrepreneurship in the last few decades has become a concern for educational institutions and policy makers, the reason is because by increasing the growth of entrepreneurs it will encourage economic development (through developing new business ideas and turning them into something profitable).

Meanwhile, McCleeland in Silvia argued that a country could develop if $2 \%$ of the total population were entrepreneurs. Entrepreneurial activities must be encouraged with courage and tenacity as well as strong determination, because entrepreneurship is fundamentally coincided with uncertainty, in terms of success or failure (Estiningsih et all, 2014 ; Hermina et all, 2011). Because only by doing business with courage and with high risk will the business grow. Technopreneur, one part of the development of entrepreneurship (entrepreneur), provides a picture of entrepreneurship using technology-based innovation. The technopreneur concept is based on the basis of technology that is used as an entrepreneurial tool, for example the emergence of online application businesses, business security systems, etc (Hermina et all, 2011).

Technopreneurship comes from a combination of the words "technology" and "entrepreneurship" Sosrowinarsidiono stated that Technopreneurship is a synergy process of a strong ability in mastery of technology and a comprehensive understanding of the concept of entrepreneurship. Herwin stated that the creation of entrepreneurs (entrepreneurs) is an alternative solution to various problems in society such as poverty and social inequality, increasing unemployment in the productive age and the depletion of energy supply reserves, all of which require creative and innovative actions (Herwin Moppanga, 2015). The entrepreneurial spirit is not only limited to academic intelligence and productproducing skills but also a dynamic spirit in capturing challenges and risks and turning them into opportunities and growth potential.
Lancang Kuning University is an institution that was founded in 1982, has activities in the field of education. Unilak is a private university which has 9 faculties in the undergraduate (S1) field and 2 postgraduate programs for undergraduate (S2). Having students studying at several faculties at Unilak come from several areas in Riau Province and from outside Riau Province there are even hose from other countries outside Indonesia, for example from Malaysia. In addition to studying college students are also given entrepreneurial activities under the Career and Entrepreneurship Development Center (P2K2). An institution under Unilak which oversees the entrepreneurial activities of lecturers, employees and students. Entrepreneurship activities are managed and carried out by the P2K2 institution by means of socialization and practice activities and in collaboration with several institutions outside Unilak, for example, youth groups in the kelurahan around Unilak. The purpose of this research is to conduct a descriptive study of entrepreneurship in students using technology (Technopreneurship) from all perspectives, both motivation, ownership, managerial, employment, and so on. Technopreneurship can be educated through the world of education as a world of transformation, namely the science of developing entrepreneurship using the basis technology as a basis for entrepreneurship.

\section{MethoD}

Leon et al stated that the factors that influence entrepreneurial intention, one of which is the family context, which shows a positive and significant relationship between family context variables on entrepreneurial intentions. Participants in the study sample also believed that their relatives (parents, siblings, and spouses) encouraged them to pursue careers as entrepreneurs, but reference groups such as friends and lecturers were the opposite (Leon et all, 2007). Other factors that influence entrepreneurial intentions are Entrepreneurial Skills. In connection with the previous family context, that based on the results of research by Hermina et al, the conditions of business opportunities are very supportive of the interest in becoming entrepreneurs. Where the business opportunity conditions can be categorized into the creativity factor and able to predict market needs (market awareness) (Hermina et all, 2011). Besides that, according to Siti it produces a strong influence between creativity (creativity) and entrepreneurial intentions. The success of forming an entrepreneurial spirit on campus is one way to meet the needs of new 


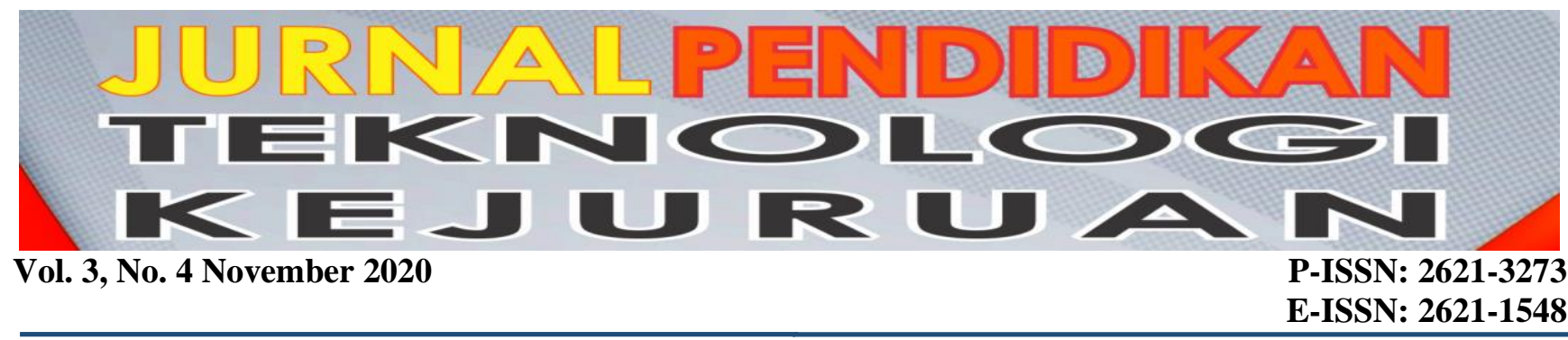

entrepreneurs in Indonesia. Currently, a number of universities have included entrepreneurship courses as compulsory courses.

Sudarsih in the Proceedings of KNIT RAMPIPB argues that technopreneurship is a process and the formation of new businesses that involve technology as the basis with the hope that the creation of appropriate strategies and innovations can put technology as a factor for national economic development. Untari stated that technopreneurship is a process in an organization that prioritizes innovation and continually finds the main problems of the organization, solves problems, and implements problem-solving methods in order to increase competitiveness in the global market (Untari et all, 2014). Students who succeed in having their own business are classified as having a very strong interest, which is shown by their enthusiasm to learn about new things in the business world and are always ready to open new businesses. That interest is positively influenced by behavioral attitudes, meaning that the stronger (positive) an individual's assessment of whether or not the impact of being entrepreneurial will strengthen the individual's desire to work independently (selfemployed) or run his own business. In this case, the stronger the attitude towards entrepreneurship, the stronger the interest in becoming an entrepreneur. Jackson and Rodkey in Akmaliah and Hisyamuddin (Akmaliah et all, 2009).

Technopreneurship has a passion for building a business which characteristically is an integration of technology application competencies. The use of cutting-edge technology is appropriate for business development based on an established entrepreneurial spirit that will optimize the process as well as the results of the developed business unit (Untari et all, 2014). In addition, technopreneurship must be successful in two ways, namely ensuring that the technology that is the object of the business can function according to the needs, target customers and can be sold to make a profit and provide benefits or impacts economically, socially and environmentally (Turker et all, 2009). Technopreneurs are new-age entrepreneurs who are interested in technology, creative, innovative, dynamic, dare to be different and take unexplored paths and are very passionate about their work
(Suryana, 2001). Technopreneur combines technology and market, ultimately boils down to business. They start a business based on technological innovation, must have a number of supporters including a strong desire to pursue achievement, conceptual skills and high problemsolving abilities, have broad insight and way of thinking, high self-confidence, tolerance, risktaking, realistic, have interpersonal skills, and controlling emotions.

\section{RESULT}

Ono in Estiningsih and Zaenal states that Entrepreneurship is the process of organizing and managing risk for a new business (Estiningsih et all, 2014). Technology is a method or method to process something in order to increase cost and time efficiency, so that it can produce higher quality products. The basics of creating technology are: market needs, solutions to problems, applications of various scientific fields, improvement of production effectiveness and efficiency, and modernization. Technology is a way or method to process something in order to increase cost and time efficiency, so that it can produce higher quality products. The basics of creating technology are: market needs, solutions to problems, application of various scientific fields, improvement of production effectiveness and efficiency, and modernization. There is a difference between ordinary entrepreneurship and technopreneurship. Technology entrepreneurship must succeed at two main tasks, namely: ensuring that technology functions according to the needs of target customers, and that technology can be sold at a profit. Ordinary entrepreneurship generally only relates to the second part, namely selling at a profit.

Education has an important role in the development of the whole human being and the development of Indonesian society as a whole. Human development must be carried out in its entirety, which includes the development of thinking power, mental power, physical strength, and mastery of science, technology, arts and sports (Slamet, 2011). In addition, human development is also expected to produce human beings who are capable and capable of playing an active role in developing Indonesian society as a whole. According to Tucker, 
this entrepreneurship education and training is a serious step by the government to overcome the growing number of educated unemployment (Turker et all, 2009). Ciputra (in the Directorate of Higher Education Institutions,) emphasized that entrepreneurship education can have a good impact on Indonesia's future, as happened in Singapore (Herwin Moppanga, 2015). However, according to Leon, the key is education must be carried out creatively. In line with that entrepreneurial practice will provide moral and material contributions to business actors (Leon et all, 2007). Putri stated that the task of the education sector, both formal and informal, is not only to produce educated people, but more broadly, the education sector must be able to create independent human beings (Putri et all, 2013). With the fact that not all of Indonesia's population of productive age and classified as the workforce can be absorbed in the world of work, the education sector is responsible for finding solutions, how to ensure that the output produced is not only oriented towards becoming workers, on the side of the role of the education sector to introduce and motivate their students so that understand that apart from being a worker, it turns out that the field of entrepreneurship is also a promising field to be explored (Turker et all, 2009).

\section{DISCUSSION}

Entrepreneurship that is carried out by students comes from several faculties in Unilak, for example from the economics faculty, engineering faculty and teacher science and education faculty. Many student entrepreneurial results have succeeded in reaching the national level, for example the Kopertis X level (LLDIKTI X) even up to the national level Kopertis level. However, from the results of student entrepreneurship there are still not many that have been developed, because many activities are carried out manually and even manually. Apart from the lack of use of technology, students are also caused by the business capital they get. The capital that students get as long as they are obtained from their own expenses and jointly with other students who are in the same group with students. So that it causes their business to be less developed, the results of their business are less known by the people inside and outside the Unilak campus. There has been much done by the University to spur the creation of young entrepreneurs on campus, but as a business incubator it is still not optimal in terms of sharing, namely not providing office facilities that can be used together, such as receptionists, conference rooms, telephone systems, fax, computers, \& security and Synergy , namely the tenant cooperation or competition between tenants and networks with universities, research institutions, private businesses, professionals and the international community has not been created.

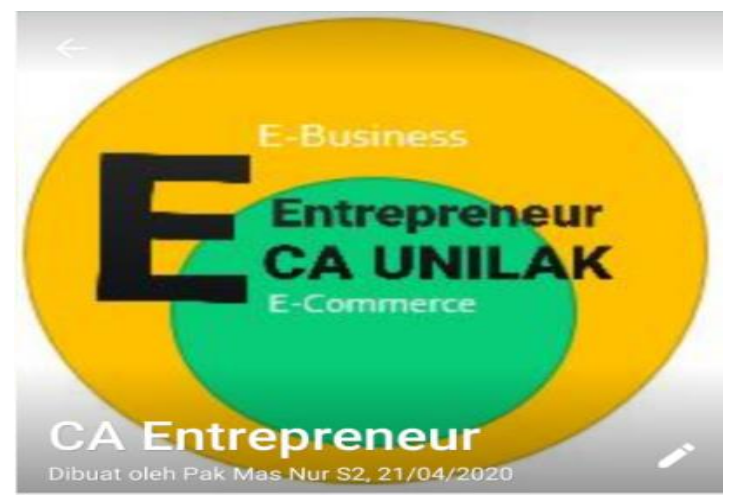

Figure 1. Technology of Entrepreneurship at Whatsapp

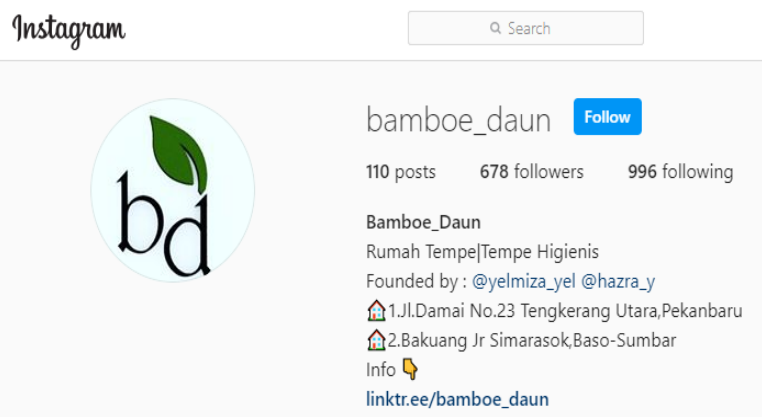

Figure 2. Technology Entrepreneurship at Instagram

The use of technology in entrepreneurship can be used by using internet facilities, for example online marketing products or business results of special students on the Unilak campus, so that it is known by campus community members such as lecturers, employees and other students. Apart from online marketing, students can also use technology, for example using computer applications by creating computer programs that can collaborate with lecturer in the field of computers and economics. By using technology both in production and marketing, it will be able to improve and develop student business results. So that it can increase student income to help with tuition fees. One of the uses of technology in product manufacturing and marketing of entrepreneurial products is already available in the form of online marketing under the name CA Entrepreneurship, which is located in Unilak. In this name the results of student products and marketing can be sent in the form of an online shop. Apart from students, it can also be used by the Unilak academic community, for example lecturers and employees. Orders can use online facilities and delivery of entrepreneurial products can be delivered 


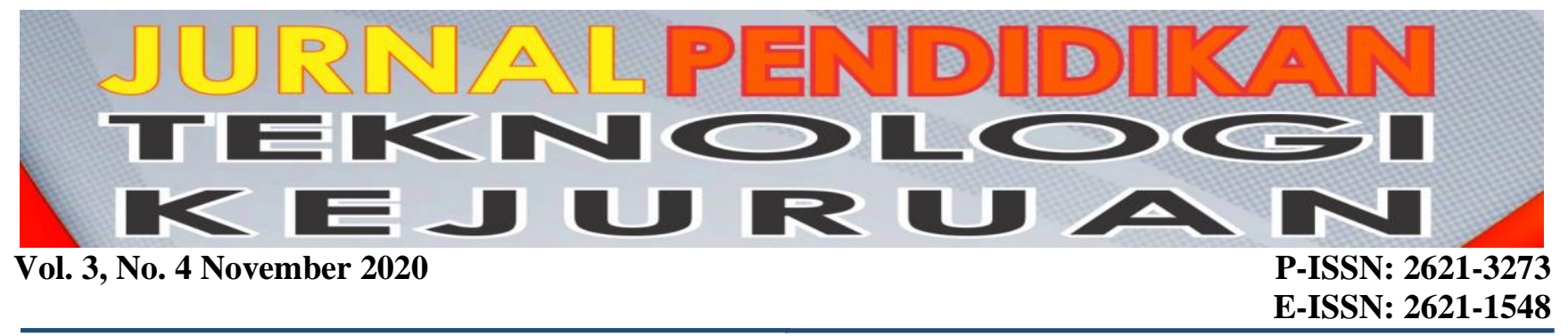

directly on the day of order or in the term one day one order.

\section{CONClusion}

Based on the results and discussion, it is found that entrepreneurship programs that have been initiated and run by various universities, especially in Indonesia, should serve as role models in starting to focus higher education in producing successful young entrepreneurs who can integrate entrepreneurial concepts and technological concepts so that they can increase the potential for business development it has. The new entrepreneurial growth program must be carried out comprehensively by involving all related parties, including universities, P2K2 institutions and university academics, business entities and non-governmental organizations. The spirit of togetherness and synergy of academics, the business world, new entrepreneurs and all other components of society need to be continuously encouraged so that more students make their choice of profession to become entrepreneurs. The use of technology (Technopreneurship) in entrepreneurship can help and develop businesses in the form of producing products as well as in product marketing, so as to increase student business and income.

\section{REFERENCES}

Akmaliah, Z., dan H. Hisyamuddin, (2009),"Choice of Self-Employment Intentions Among Secondary School Studens", The Journal of International Social Research, Vol 2(9), pp.539-549

Anata, Firdaus, 2013, Pengaruh Tingkat Pengangguran Terbuka, PDRB Perkapita, Jumlah Penduduk dan Indeks Williamson Terhadap Ttingkat Kriminalitas (Studi pada 31 Propinsi di Indonesia tahun 2007 - 2012), Jurnal Ilmiah Fakultas Ekonomi Dan Bisnis, Universitas Brawijaya, Malang.

Asri Laksmi Riani. 2005. Dasar-dasar Kewirausahaan. Surakarta: UNS Press
Clelland, David MC. (1961). Entrepreneur Behavior And Characteristics of Entrepreneurs. The Achieving Society.

Estiningsih, Wening. Zainal, Arifin, HM, 2014, Technoprenuership; Challenge For Entrepreneurship Educational Development in Indonesia, Forum Tahunan Pengembangan Iptek dan Inovasi Nasional IV, LIPI

Hermina, U.N., Novieyana, S., dan Zain, D. 2011. Pengaruh Mata Kuliah Kewirausahaan Terhadap Minat Mahasiswa Menjadi Wirausaha. Jurnal

Herwin Moppanga, 2015, Studi Kasus Pengembangan Wirausaha Berbasis Tekhnologi (Technopreneurship) di Provinsi Gorontalo, Journal Trikonomika, Volume.14 no.1.

Kartadinata, Sunaryo, 2009, Membangun Keutuhan Bangsa Melalui Pendidikan Dalam Bingkai Utuh Sistem Pendidikan Nasional, Universitas Pendidikan Indonesia, Bandung

Leon, J.A., Descals, F.J., and Dominguez, J.F, 2007. The Psychosocial Profile Of The University Entrepreneur. Journal of Psychology in Spain, 11(1), pp: 72-84.

Putri, Novita Delima, 2013, Pendidikan Kewirausahaan; Sebagai sebuah Tantangan Bagi Pengembangan Pendidikan Indonesia, Prossiding Seminar Nasional: Sustainable Competitive Advantages - 3. Unsoed, Purwokerto.

Slamet, PH (2011), Peran Pendidikan Vokasi Dalam Pembangunan Ekonomi, Cakrawala Pendidikan, Juni 2011, Th. XXX, No. 2.

Suryana. 2001. Kewirausahaan. Edisi Pertama. Jakarta: Salemba Empat.

Turker, D. and Senem S.S. 2009. Which Factors Affect Entrepreneurial Intention of University Students?. Journal of European Industrial Training, 3(2), pp: 142-159. 
Untari, Dhian Tyas. (2014). Ecopreneurship: Concept Of Responsible Entrepreneurship. Malang: Prosiding 11th International Annual Symposium on Management. 